\title{
James V. Neel and Latin America - or how scientific collaboration should be conducted
}

Francisco M. Salzano

\begin{abstract}
The main events related to the life of James V. Neel, one of the most important geneticists of the last decades, are presented, especially with reference to the influence he exerted in Latin America. Documentation is provided on the field work he performed in Brazil, and on the results of the joint Ann Arbor-Porto Alegre program of research.
\end{abstract}

\section{BIOGRAPHIC NOTES}

On February 1, 2000, science lost one of its most devoted followers, James van Gundia Neel (Figure 1). His life extended for 84 most incredibly productive years, involving studies that covered almost all aspects of human genetics. Although North American, he was a citizen of the world, and circunstances related to his research interests brought him in close contact especially with colleagues and population groups of Japan, Brazil, and Venezuela. It would be an impossible task to review, in the space available, all aspects of his professional career and personal life. I will attempt here to just highlight some main events, especially those related to Latin America.

Table I presents, in chronological order, the main events of his life. As most geneticists who started their careers in the first half of the 20th century, his introduction to this science was through the fruit fly Drosophila. But in the beginning of the 1940s he became increasingly interested in human genetics, his first paper on this subject occurring in 1943 (Neel, 1943). More than half-a-thousand full scientific papers and six books were subsequently produced, documenting his fantastic work capacity and phenomenal erudition.

At the beginning of his career, Neel was most interested in clinical genetics and genetic counseling. In the late 1940 's and in the 1950's he then became increasingly concerned with the genetics and population distribution of the hemoglobinopathies, and he was the first (Neel, 1949) to establish the genetic basis for sickle cell anemia. His studies on the aftereffects of atomic radiation on survivors of Hiroshima and Nagasaki extended for half a century (review in Neel and Schull, 1991). The Japanese studies also included extensive investigations on the effects of inbreeding (see, for instance, Schull and Neel, 1965). During the 1960's he proposed the "thrifty gene" hypothesis, suggesting that genes associated with common modern diseases like diabetes, hypertension, and obesity have been preserved because they helped our ancestors to survive when calories and salt were less abundant (Neel, 1962). His long-term (four decades) interest in the genetics and evolution of Amerindians should also be emphasized, leading to the development of a new model of population structure (Neel and Salzano, 1967). One of his last specific interests originated from observations of the chromosomes of badly damaged cells among the Yanomama Indians (the so-called "rogue" cells) afterwards observed also in Japan and Russia (Neel et al., 1992). They probably result from infections with human polyomaviruses, and may be implicated in the oncogenesis process.

As a result of his achievements, Neel received many distinctions along his career. Not less than 30 Awards and Honors, received between 1955 and 1999, are listed in his curriculum vitae, and a few of them are indicated in Table I.

He has had a personal happy and fruitful family life. The marriage with Priscilla Baxter, on May 6, 1943, ended with his death only. In several instances I enjoyed their hospitality in the nice house they had at 2235 Belmont Street in Ann Arbor, and could testify to their generally undisturbed relationship. He is survived by Priscilla, a daughter, Frances, a social worker who lives in Ann Arbor; and two sons, both practicing physicians, one (James Jr.) working in Santa Rosa, $\mathrm{CA}$, and the other (Alexander) in Dodge City, KS. Additional survivors include three grandchildren and a sister.

\section{PERSONAL RECOLLECTIONS - THE GREEN YEARS}

Let us go back now almost half a century ago. In 1955 I was finishing my Ph.D. studies, working with Drosophila, and was obviously concerned about future research. After

Part of this paper was read at the Memorial Service held to honor James V. Neel at the University of Michigan, Ann Arbor, MI, USA on May 22, 2000. Departamento de Genética, Instituto de Biociências, UFRGS, Caixa Postal 15053, 91501-970 Porto Alegre, RS, Brasil. Fax: +55-51-319-2011 E-mail: salzano@if.ufrgs.br 


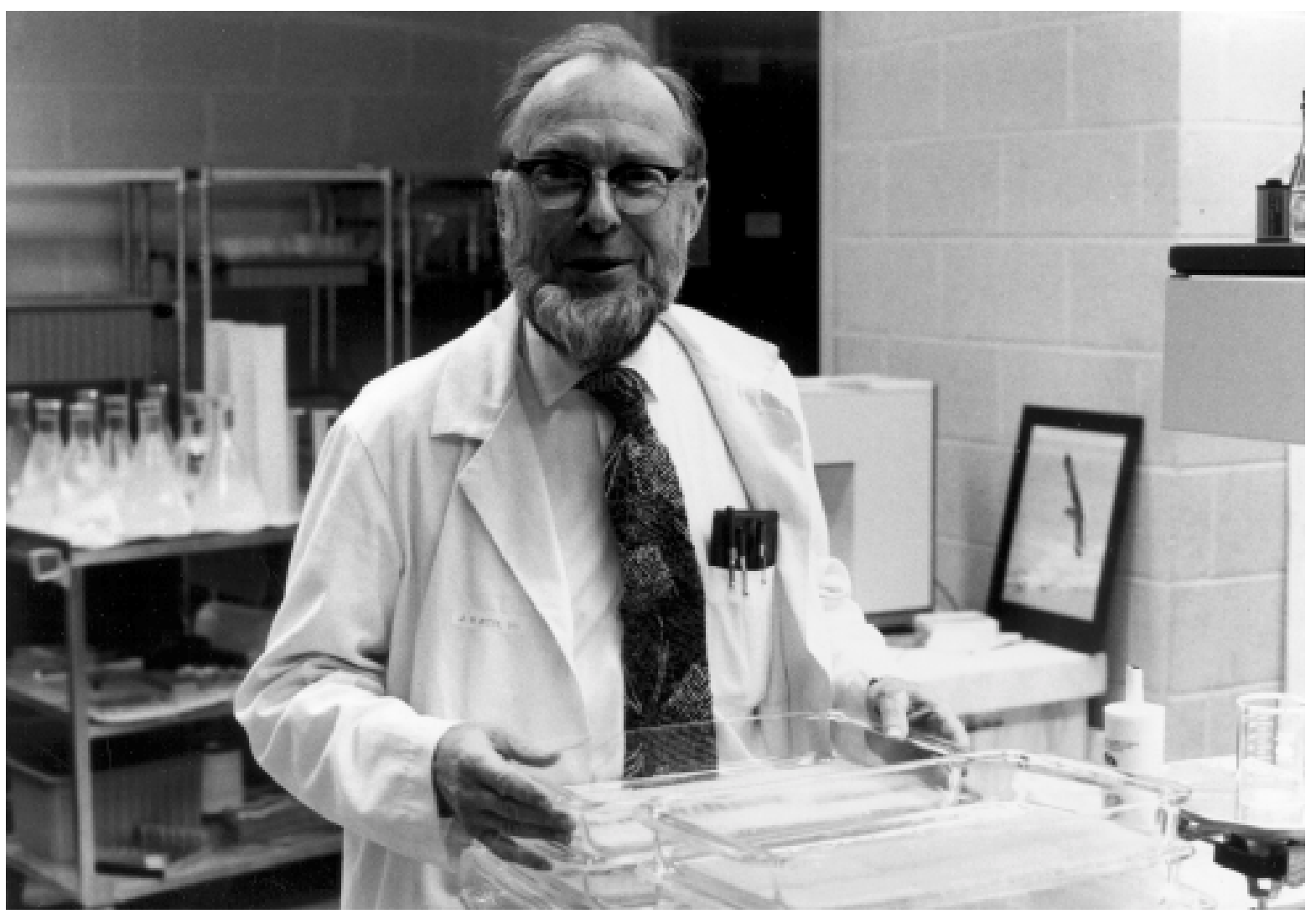

Figure 1 - James V. Neel examining the results of electrophoretic runs at his laboratory in Ann Arbor in the late 1970's.

Table I - Main events related to the life of James V. Neel.

\begin{tabular}{|c|c|}
\hline Year & Main event \\
\hline 1915 & Was born on March 22 in Hamilton, OH, USA. \\
\hline 1925 & His father died of pneumonia, and life thereafter did not become easy financially. Move from Detroit to Wooster, $\mathrm{OH}$. \\
\hline $1931-1935$ & $\begin{array}{l}\text { Undergraduate studies at the College of Wooster. Decision to work in Genetics (Drosophila) under } \\
\text { Warren Spencer's influence. }\end{array}$ \\
\hline 1935-1939 & Ph.D. studies (also with Drosophila) at the University of Rochester, NY, under Curt Stern's guidance. \\
\hline 1939-1940 & First academic position at Dartmouth College, Hanover, NH. \\
\hline 1941-1942 & $\begin{array}{l}\text { National Research Council fellowship at Columbia University. Work with Drosophila, in association with } \\
\text { Theodosius Dobzhansky. }\end{array}$ \\
\hline 1942-1944 & Studies at the University of Rochester Medical School. Acquisition of a MD degree. \\
\hline 1943 & Marriage with Priscilla Baxter on May 6. \\
\hline 1944-1948 & $\begin{array}{l}\text { Military service at Waltham General Hospital, Murphy General Hospital, and Japan. The full program related to the } \\
\text { survivors of the atomic bombing began in February of 1948, in Hiroshima. }\end{array}$ \\
\hline 1948 & $\begin{array}{l}\text { Start of work in March at the University of Michigan, especially its Heredity Clinic, one of the first in the USA (it is not } \\
\text { clear whether it antedated or not a similar clinic established at the University of Minnesota by Sheldon C. Reed). }\end{array}$ \\
\hline 1953-1954 & President, American Society of Human Genetics. \\
\hline 1956 & Chairman of the newly created Department of Human Genetics, the first of its kind in the USA. \\
\hline 1960-1961 & Farewell as attending physician at the University of Michigan Hospitals. \\
\hline 1955 & Trip to Africa, related to his interests in the hemoglobinopathies. \\
\hline 1961 & End of main involvement with the hemoglobinopathies. \\
\hline 1962 & First field work among the Xavante of Central Brazil. \\
\hline 1963 & Elected as a Member of the USA National Academy of Sciences. \\
\hline 1965 & Allan Award, American Society of Human Genetics. \\
\hline 1966 & First field work among the Yanomama of Venezuela. \\
\hline 1975 & National Medal of Science. \\
\hline 1981 & $\begin{array}{l}\text { President, Sixth International Congress of Human Genetics, Israel. End of chairmanship at the Department of Human } \\
\text { Genetics of the University of Michigan. }\end{array}$ \\
\hline 1985 & Formal compulsory retirement, at age 70. He continued his studies, as Emeritus Professor, until his death. \\
\hline 1997 & Ibero-American Society of Human Genetics Annual Award. \\
\hline 2000 & Died from cancer on February 1. \\
\hline
\end{tabular}


consultation with Prof. Antonio R. Cordeiro, who had organized Porto Alegre's Genetics Group in 1949, we decided that a promising field would be human genetics. I then went to examine the American Journal of Human Genetics, then at its seventh year of publication, to see where I could go in a post-doctoral program. James Neel was contributing regularly to the journal since its first number, and was one of the obvious choices. At that time the Rockefeller Foundation had an active program of support of Brazilian genetics, which was fundamental for its development, and provided post-doctoral fellowships. Consulted on this matter, the Rockefeller officer responsible for the program, Dr. Harry M. Miller Jr., was very enthusiastic about the research that was going on in Ann Arbor, and on the benefits that I could have on this stay. Actually another Brazilian had been working already in Ann Arbor under Jim's guidance, Eduardo Barbosa Vianna, at the Heredity Clinic, while Newton Freire-Maia, also a Brazilian, was planning to go there at the beginning of 1956.

When I arrived in Ann Arbor by train, at the end of August, 1956, Freire-Maia was alredy waiting for me at the station, and had arranged an apartment for my stay in the same house he was living. Therefore, my arrival and first days were much facilitated by my colleague. When I first met Jim he was 41 years old, while I was 28 . His first remark was that he expected someone older, to which I replied that time would take care of that, and it did, as those who know me personally now can easily testify! The year I stayed in Ann Arbor was most enjoyable, moving around streets like Catherine and Ann, that Freire-Maia said were all names of his former domestic maids!

At the end of my stay Jim and I discussed plans for my work in Brazil, and the Amerindians appeared at the forefront, since their gene pool and ways of living were different from those prevailing in First World countries; therefore, they could more easily provide original information. We were at the beginning of a project that would occupy most of our lives.

\section{A TRAINING CENTER FOR LATIN AMERICANS}

In the ensuing years Ann Arbor became a center of reference and training for Latin Americans (as was true, of course, in relation to persons from other countries, especially Japan). As was already mentioned, two South American countries in which extensive collaborative projects were undertaken were Brazil and Venezuela; and a certainly incomplete list of researchers from these countries who stayed for extended periods of time in Ann Arbor included, in alphabetical order, the following Brazilians: Antonio L. Cavalcanti, Eucleia P.B. Contel, Fernando J. da Rocha, Manuel Ayres, and Pedro H. Saldanha; and the following Venezuelans: Charles Brewer-Carias, Esperanza Garcia, Miguel and Zulay Layrisse, and Tulio Arends. In connection with studies in Costa Rica, the name of Ramiro Barrantes should be mentioned, while Francisco Rothhammer, from
Chile, and Antonio Velazquez, from México, also benefited from prolonged stays there. In recognition to his role in the development of human genetics in Brazil, Jim was elected a Corresponding Member of the Brazilian Academy of Sciences in 1979.

\section{HUMANEVOLUTION}

The need to establish multidisciplinary studies for the investigation of the genetics of groups whose subsistence was based on hunting-gathering with incipient agriculture was in the minds of many scholars in the late 1950's. This was due, of course, to the fact that these populations were those that best resembled those that prevailed during most of our evolutionary history. Prof. James V. Neel, however, was the most vigorous advocate in relation to this approach. After careful planning (described in detail in his book "Physician to the Gene Pool"; Neel, 1994) field work was performed among the Xavante Indians of Central Brazil in 1962, and the results of this first, pilotstudy, published two years later (Neel et al., 1964), became an obligatory reference for any one interested in this area. Also in 1962 two other events significantly influenced by him took place: a) a meeting at the World Health Organization in Geneva, where a selected group of experts indicated the philosophy and methodology to be followed in these studies, and b) the launching, by the International Council of Scientific Unions, of an International Biological Program in which these studies would be coordinated.

The results of these endeavors have been appropriately published in numerous scientific articles, books and monographs. In relation specifically to the Ann ArborPorto Alegre program I would mention that it involved my return to Ann Arbor in 1965, 1972, 1976, and 1981 to prepare the results obtained for publication; and a list of the resulting chapters of books and articles is given at the Appendix. One book and one article, published independently by ourselves (Salzano and Callegari-Jacques, 1988; Callegari-Jacques et al., 2000) were dedicated to Jim when he was still alive, in appreciation to the influence he had in our ways of thinking and doing science.

\section{LIFE IN THE JUNGLE}

Americans and Brazilians, under Jim's coordination, performed five rounds of field work. The above-mentioned 1962 expedition; additional studies among the Xavante in 1964; investigations on the Brazilian Yanomama in 1967; visits to the Krahó, Gorotire, Macuxi and Wapishana in 1974, and the expedition based on the Alpha Helix ship in 1976, which involved surveys among the Ticuna, Baniwa, Kanamari and Central Pano.

As for the Venezuelan investigations, after the first contacts in 1964, a series of expeditions took place among the Yanomama, making of this group the most well-studied tribal society in all world. 
I could tell many stories about these field trips, but will present only two. Jim had the philosophy that "one should be prepared for any eventuality that may occur in the field". Therefore, he would arrive in Brazil with a voluminous baggage which included several trunks, that due to their weight were a constant torment for all of us. In the first trip to the Xavante he decided to take an enormous electrical generator to the field, to assure that this type of energy would be available to us there. The transportation of such a weighty apparatus was only made possible because the Brazilian Air Force made a DC-3 airplane available for our exclusive use in the trip to the field. Considerable efforts were spent to transport the generator from the air strip to a place near the Indian Foundation Post, but we finally managed to do it; and during all the period we remained in the field all spared time was taken by Jim and the Indian Foundation officer to make it function, without any success. After our return it remained there, and probably is now covered by vegetation, as a symbol of the triumph of nature over the man-made artifacts!

Some years afterwards we were navigating the Amazon aboard the Alpha Helix and arrived at a place symptomatically called Vendaval (meaning stormy winds). After a round of field work, at the evening, as we prepared to come back to the ship in motorboats, a storm started to form. Some people suggested that we should stay in the village until the end of the storm, but the technician who was in charge of the motorboat decided that we should come back. As we started moving towards the ship the storm became especially intense, and the rain was so heavy that we barely could see the ship at a distance. Since we were not progressing due to the waves, it was suggested that two volunteers should step out of the boat, to make it lighter. Jim's son, James Jr., and myself, volunteered and were left among some marshy vegetation, covered by water up to the waist, and quivering due to cold in the heart of the tropics! Only about three hours later a motorboat came to rescue us.

In the next day the weather remained bad, with rains, clouds, and winds, and the question was whether we should come back to the village, where the Indians would be gathering for examination, or not. The decision was left to the beginning of the afternoon, and when at mid-morning I went to the ship's deck I saw Jim there looking to the sky, and the clear impression I had it was that he was arguing with God about the situation! Finally the weather improved somewhat and we were able to go to the village and come back from it without problems.

\section{THE PERSON AND THE SCIENTIST}

My relationship with James V. Neel extended for a period of 44 years; after that first year in Ann Arbor we met at regular intervals in the United States, Brazil and elsewhere, at different scientific meetings. Formally our scientific collaboration extended from 1964 to 1994, dates of the first and last paper we have published together. But his influence transcended that, pervading all of my career. His example of intellectual honesty, sense of responsibility, perseverance, and incredible intellectual ability standed always to me and many other colleagues in the profession as a paradigm to be followed. The elegance of his attitude when fiercely attacked by other professionals will always be admired. He was strong, physically and intellectually; the last time I met him personally, in October, 1997, at the age of 82 and with ill health, he was most willing to use the stairs, instead of the elevator, to move from one floor to another at the convention center where we were. His disappearance created a vacuum both in the scientific world and in the deep inside of all who loved and revered him that may probably never be filled. But his personality, as a man and as a scientist, will remain forever as an example to be followed.

\section{RESUMO}

Apresentação dos principais eventos relacionados com a vida de James V. Neel, um dos mais importantes geneticistas das últimas décadas, especialmente com referência à influência que ele exerceu na América Latina. É fornecida documentação sobre o trabalho de campo que ele realizou no Brasil, e sobre os resultados do programa comum Ann Arbor-Porto Alegre de pesquisa.

\section{REFERENCES}

Callegari-Jacques, S.M., Flowers, N.M., Laner, N.F.M. and Salzano, F.M. (2000). Demography and genetics at the tribal level: the Xavante as a test case. Curr. Anthropol. (in press).

Neel, J.V. (1943). Concerning the inheritance of red hair. J. Hered. 34: 93-96.

Neel, J.V. (1949). The inheritance of sickle cell anemia. Science 110: 64-66.

Neel, J.V. (1962). Diabetes mellitus: a "thrifty" genotype rendered detrimental by "progress"? Am. J. Hum. Genet. 14: 353-362.

Neel, J.V. (1994). Physician to the Gene Pool. Genetic Lessons and other Stories. John Wiley, New York.

Neel, J.V. and Salzano, F.M. (1967). Further studies on the Xavante Indians. $\mathrm{X}$. Some hypotheses-generalizations resulting from these studies. Am. J. Hum. Genet. 19: 554-574.

Neel, J.V. and Schull, W.J. (1991). The Children of Atomic Bomb Survivors. A Genetic Study. National Academy Press, Washington, D.C.

Neel, J.V., Salzano, F.M., Junqueira, P.C., Keiter, F. and Maybury-Lewis, D. (1964). Studies on the Xavante Indians of the Brazilian Mato Grosso. Am. J. Hum. Genet. 16: 52-140.

Neel, J.V., Awa, A.A., Kodama, Y., Nakano, M. and Mabuchi, K. (1992). "Rogue" lymphocytes among Ukrainians not exposed to radioactive fall-out from the Chernobyl accident: the possible role of this phenomenon in oncogenesis, teratogenesis, and mutagenesis. Proc. Nat. Acad. Sci. USA 89: 6973-6977.

Salzano, F.M. and Callegari-Jacques, S.M. (1988). South American Indians. A Case Study in Evolution. Clarendon Press, Oxford.

Schull, W.J. and Neel, J.V. (1965). The Effects of Inbreeding on Japanese Children. Harper and Row, New York.

(Received June 9, 2000) 


\section{APPENDIX}

List (in chronological order) of the publications which resulted from the Ann Arbor-

Porto Alegre collaboration

\section{Chapters of books}

Neel, J.V. and Salzano, F.M. (1966). A prospectus for genetic studies on the American Indians. In: The Biology of Human Adaptability (Baker, P.T. and Weiner, J.S., eds.). Clarendon Press, Oxford, pp. 245-274.

Neel, J.V., Layrisse, M. and Salzano, F.M. (1977). Man in the tropics: the Yanomama Indians. In: Population Structure and Human Variation (Harrison, G.A., ed.). Cambridge University Press, Cambridge, pp. 109142.

\section{Full scientific articles}

Salzano, F.M. and Sutton, H.E. (1963). Haptoglobin and transferrin types in southern Brazilian Indians. Acta Genet. Stat. Med. 13: 1-8.

Tondo, C.V., Salzano, F.M. and Rucknagel, D.L. (1963). Hemoglobin Porto Alegre, a possible polymer of normal hemoglobin in a Caucasian Brazilian family. Am. J. Hum. Genet. 15: 265-279.

Tondo, C.V., Salzano, F.M. and Rucknagel, D.L. (1963). A new inherited hemoglobin abnormality in a Caucasian Brazilian family. Proc. 2nd Int. Congr. Hum. Genet: 660-663.

Neel, J.V., Salzano, F.M., Junqueira, P.C., Keiter, F. and Maybury-Lewis, D. (1964). Studies on the Xavante Indians of the Brazilian Mato Grosso. Am. J. Hum. Genet. 16: 52-140.

Neel, J.V. and Salzano, F.M. (1964). A prospectus for genetic studies of the American Indian. Cold Spring Harbor Symp. Quant. Biol. 29: 85-98.

Salzano, F.M. and Shreffler, D.C. (1966). The Gc polymorphism in the Caingang Indians of Brazil. Acta Genet. Stat. Med. 16: 242-247.

Salzano, F.M. and Neel, J.V. (1967). Fertility patterns and genetic structure of Xavante Indian populations. Ciênc. Cult. 19: 64-66.

Salzano, F.M., Neel, J.V. and Maybury-Lewis, D. (1967). Further studies on the Xavante Indians. I. Demographic data on two additional villages: genetic structure of the tribe. Am. J. Hum. Genet. 19: 463-489.

Gershowitz, H., Junqueira, P.C., Salzano, F.M. and Neel, J.V. (1967). Further studies on the Xavante Indians. III. Blood groups and ABH-Lea Secretor types in the Simões Lopes and São Marcos Xavantes. Am. J. Hum. Genet. 19: 502-513.

Weinstein, E.D., Neel, J.V. and Salzano, F.M. (1967). Further studies on the Xavante Indians. VI. The physical status of the Xavantes of Simões Lopes. Am. J. Hum. Genet. 19: 532-542.

Neel, J.V. and Salzano, F.M. (1967). Further studies on the Xavante Indians. $\mathrm{X}$. Some hypotheses-generalizations resulting from these studies. Am. J. Hum. Genet. 19: 554-574.

Salzano, F.M., Gershowitz, H., Junqueira, P.C., Woodall, J.P., Black, F.L. and Hierholzer, W. (1972). Blood groups and H-Le ${ }^{\mathrm{a}}$ salivary secretion of Brazilian Cayapo Indians. Am. J. Phys. Anthropol. 36: 417-426.

Salzano, F.M., Neel, J.V., Weitkamp, L.R. and Woodall, J.P. (1972). Serum proteins, hemoglobins and erythrocyte enzymes of Brazilian Cayapo Indians. Hum. Biol. 44: 443-458.

Neel, J., Arends, T., Brewer, C., Chagnon, N., Gershowitz, H., Layrisse, M., Layrisse, Z., MacCluer, J., Migliazza, E., Oliver, W., Salzano, F.M., Spielman, R., Ward, R. and Weitkamp, L. (1972). Studies on the Yanomama Indians. Proc. 4th Int. Congr. Hum. Genet.: 96-111.

Seid-Akhavan, M., Ayres, M., Salzano, F.M., Winter, W.P. and Rucknagel, D.L. (1973). Two more examples of Hb Porto Alegre $\alpha_{2} \beta_{2}$ 9Ser->Cys in Belém, Brazil. Hum. Hered. 23: 175-181.
Rothhammer, F., Neel, J.V., da Rocha, F.J. and Sundling, G.Y. (1973). The genetic structure of a tribal population. The Yanomama Indians. VIII. Dermatoglyphic differences among villages. Am. J. Hum. Genet. 25: 152-166.

Da Rocha, F.J., Spielman, R.S. and Neel, J.V. (1974). A comparison of gene frequencies and anthropometric distance matrices in seven villages of four Indian tribes. Hum. Biol. 46: 295-310.

Mestriner, M.A., Salzano, F.M., Neel, J.V. and Ayres, M. (1976). Esterase D in South American Indians. Am. J. Hum. Genet. 28: 257-261.

Salzano, F.M. and Neel, J.V. (1976). New data on the vision of South American Indians. Bull. Pan Am. Health Organ. 10: 1-8.

Neel, J.V., Tanis, R.J., Migliazza, E.C., Spielman, R.S., Salzano, F.M., Oliver, W.J., Morrow, M. and Bachofer, S. (1977). Genetic studies of the Macushi and Wapishana Indians. I. Rare genetic variants and a "private polymorphism" of esterase A. Hum. Genet. 36: 81-107.

Neel, J.V., Gershowitz, H., Spielman, R.S., Migliazza, E.C., Salzano, F.M. and Oliver, W.J. (1977). Genetic studies of the Macushi and Wapishana Indians. II. Data on 12 genetic polymorphisms of the red cell and serum proteins: gene flow between the tribes. Hum. Genet. 37: 207-220.

Salzano, F.M., Neel, J.V., Gershowitz, H. and Migliazza, E.C. (1977). Intraand intertribal genetic variation within a linguistic group: the Ge-speaking Indians of Brazil. Am. J. Phys. Anthropol. 47: 337-348.

Salzano, F.M., Pagés, F., Neel, J.V., Gershowitz, H., Tanis, R.J., Moreno, R. and Franco, M.H.L.P. (1978). Unusual blood genetic characteristics among the Ayoreo Indians of Bolivia and Paraguay. Hum. Biol. 50: 121-136.

Mohrenweiser, H., Neel, J.V., Mestriner, M.A., Salzano, F.M., Migliazza, E., Simões, A.L. and Yoshihara, C.M. (1979). Electrophoretic variants in three Amerindian tribes. The Baniwa, Kanamari, and Central Pano of western Brazil. Am. J. Phys. Anthropol. 50: 237-246 (Portuguese version in Acta Amaz. 9: 99-108, 1979).

Lawrence, D.N., Facklam, R.R., Sottnek, F.O., Hancock, G.A., Neel, J.V. and Salzano, F.M. (1979). Epidemiologic studies among Amerindian populations of Amazonia. I. Pyoderma: prevalence and associated pathogens. Am. J. Trop. Med. Hyg. 28: 548-558 (Portuguese version in Acta Amaz. 9: 661-673, 1979).

Lawrence, D.N., Erdtmann, B., Peet, J.W., Nunes de Mello, J.A., Healy, G.R., Neel, J.V. and Salzano, F.M. (1979). Epidemiologic studies among Amerindian populations of Amazônia. II. Prevalence of Mansonella ozzardi. Am. J. Trop. Med. Hyg. 28: 991-996 (Portuguese version in Acta Amaz. 10: 763-769, 1980).

Salzano, F.M., Callegari Jacques, S.M. and Neel, J.V. (1980). Genetic demography of the Amazonian Ticuna Indians. J. Hum. Evol. 9: 179-191 (Portuguese version in Acta Amaz. 9: 517-527, 1979).

Salzano, F.M., Callegari Jacques, S.M. and Neel, J.V. (1980). Demographic and genetic relationships among Brazilian Wapishana Indians. Ann. Hum. Biol. 7: 129-138.

Neel, J.V., Gershowitz, H., Mohrenweiser, H.W., Amos, B., Kostyu, D.D., Salzano, F.M., Mestriner, M.A., Lawrence, D., Simões, A.L., Smouse, P.E., Oliver, W.J., Spielman, R.S. and Neel Jr., J.V. (1980). Genetic studies on the Ticuna, an enigmatic tribe of Central Amazonas. Ann. Hum. Genet. 44: 37-54.

Salzano, F.M., Mohrenweiser, H., Gershowitz, H., Neel, J.V., Mestriner, M.A., Simões, A.L., Constans, J. and de Melo e Freitas, M.J. (1984). New studies on the Macushi Indians of northern Brazil. Ann. Hum. Biol. 11: 337-350.

Salzano, F.M., Gershowitz, H., Mohrenweiser, H., Neel, J.V., Smouse, P.E., Mestriner, M.A., Weimer, T.A., Franco, M.H.L.P., Simões, A.L., Constans, J., Oliveira, A.E. and de Melo e Freitas, M.J. (1986). Gene flow across tribal barriers and its effect among the Amazonian Içana River Indians. Am. J. Phys. Anthropol. 69: 3-14.

Rodriguez-Delfin, L.A., Salzano, F.M., Callegari-Jacques, S.M. and Neel, J.V. (1994). Blood polymorphisms and morphological variability in Brazilian Indians. Am. J. Hum. Biol. 6: 619-626. 
